\title{
Red Blood Cells Derived from Whole Blood Treated with Riboflavin and UV Light Maintain Adequate Cell Quality through 21 Days of Storage
}

\author{
Lina Y. Dimberg ${ }^{a}$ Suzann K. Doane ${ }^{a}$ Susan Yonemura ${ }^{a}$ Heather L. Reddy \\ Nick Hovenga $^{a}$ E. Jane Gosney ${ }^{a}$ Melissa Tran ${ }^{a}$ Shilo Wilkinson ${ }^{a}$ \\ Raymond P. Goodrich ${ }^{\mathrm{b}}$ Susanne Marschner ${ }^{\mathrm{a}}$ \\ ${ }^{a}$ Terumo BCT, Lakewood, CO, USA; ${ }^{b}$ Infectious Disease Research Center, Colorado State University, \\ Fort Collins, CO, USA
}

\section{Keywords}

Blood transfusion · Pathogen reduction · Red blood cells . Blood safety

\begin{abstract}
Background: The Mirasol system for whole blood (WB) is a non-toxic, non-mutagenic pathogen reduction technology (PRT) that treats WB units with riboflavin (vitamin $B_{2}$ ) and $u l-$ traviolet (UV) light to alter nucleic acids, thereby reducing pathogen infectivity and inactivating white blood cells. This study evaluates the quality of red blood cells (RBCs) derived from WB treated with the Mirasol system. Study Design and Methods: Paired units of WB were collected from 61 healthy donors. One unit per donor was treated with riboflavin and UV light and the other was used as an untreated control. RBCs were processed from the WB units and stored in AS-3 at $1-6^{\circ} \mathrm{C}$ for 21 days and sampled for in vitro analyses of RBC quality parameters. Results: Several statistically significant differences were observed between test and control units, but values were overall within normal clinical ranges. After leukoreduction, the residual leukocyte count and $\mathrm{RBC}$ recovery met FDA requirements. The RBC units derived from treated WB maintained haemolysis below $1 \%$ through 21 days of storage. Conclusion: RBCs derived from WB treated with the Mirasol system meet accepted FDA guidelines for RBC quality through 21 days of storage at $1-6^{\circ} \mathrm{C}$.
\end{abstract}

(c) 2019 S. Karger AG, Basel

\section{Introduction}

To reduce the risk of transfusion-transmitted infections (TTIs), safety measures such as donor screening and deferral procedures, as well as serologic and nucleic acid testing (NAT), have been introduced. These procedures have greatly increased blood safety but have limitations. Donor screening and deferral rely heavily on risk factors being accurately defined and disclosed. Serological testing and NAT are effective, but costly and time-consuming to develop for each new pathogen. Furthermore, tests will give false-negative results if a blood donation is made within the window period between donor infection and detectable pathogen load. This residual risk from screened pathogens is small but not negligible, especially for patients in countries with a higher prevalence of bloodborne pathogens, for immune-suppressed patients, and for chronically transfused patients with a higher cumulative risk of TTIs than that of the average transfusion recipient. The risk associated with emerging pathogens without available or implemented screening tests may be an even greater threat to the safety of the global blood supply, as exemplified by the experience from the HIV epidemic when more than 8,000 people were infected by HIV through blood transfusions in the USA between 1985 and 1993 [1].

The presence of residual white blood cells (WBCs) from the donor in the blood product may result in serious complications such as febrile non-haemolytic transfusion

\section{KARGER}

(C) 2019 S. Karger AG, Basel 
reaction, alloimmunization, and the rare life-threatening transfusion-associated graft-versus-host disease (TAGvHD). Gamma irradiation using cesium chloride irradiators is the current standard of care for preventing TAGvHD. A potential public safety issue is that radioactive cesium is highly water soluble and dispersible, and can be exploited in the making of radiological dispersal devices, i.e. "dirty bombs" [2].

Pathogen reduction technology (PRT) provides a proactive approach to enhancing blood safety that broadly targets both pathogens and WBCs. The Mirasol system for whole blood (WB) uses ultraviolet (UV) light energy and riboflavin to induce DNA and RNA breaks. The riboflavin acts as a photosensitizer, making the nucleic acid damage irreversible through modification of guanine bases [3]. Nucleic acid replication is irrelevant for non-nucleated cells such as red blood cells (RBCs), but is necessary for the propagation of pathogens and WBCs. Thus, the Mirasol process can decrease the risk both of TTIs due to pathogens and of immune-mediated reactions due to residual WBCs.

Because the Mirasol system targets nucleic acids, it targets both pathogens and cells that are dependent on DNA or RNA for replication. The Mirasol system has been shown to reduce infectious levels of HIV [4], several bacterial strains [5], and parasites [6-9]. The process inactivates WBCs as well as or better than gamma irradiation and prevents xenogeneic GvHD, an animal model for TA-GvHD [10]. The clinical study African Investigation of Mirasol System for Whole Blood (AIMS) demonstrated for the first time in humans a significantly lower transmission of the Plasmodium parasite, which causes malaria, in transfused WB treated with the Mirasol process as compared to untreated WB [11].

One advantage of the Mirasol system is the safety of the photosensitizer. Riboflavin (vitamin $\mathrm{B}_{2}$ ) and its main photoproduct, lumichrome, occur naturally in the human diet and are present in human blood [12]. Riboflavin and its photoproducts, as well as blood products treated with the Mirasol system, have been characterized in vitro and in several animal models [13-16].

The Mirasol system also encompasses the treatment of plasma and platelet components. The same photosensitizer (riboflavin) is used, as is the same UV-light spectrum, albeit at a lower total energy dose. The reason why a higher total energy dose is required for WB treatment is that the haemoglobin $(\mathrm{Hb})$ present in the RBCs absorbs UV light. The Mirasol system for platelets and the Mirasol system for plasma are currently used in more than 20 different countries, and the Mirasol system for WB has recently been Conformité Européenne (CE) marked. Mirasol-treated WB retains haemostatic function [17], and there is considerable interest in developing methods to derive all components from Mirasol-derived WB [18]. However, protocols have not yet been optimized [18]. In the USA, Mirasol-treated apheresis platelets in plasma and RBCs derived from Mirasol-treated WB are investigational products in clinical development under approved investigational device exemptions.

Given the safe nature of the Mirasol system photosensitizer and the demonstrated efficacy of pathogen reduction and WBC inactivation, the Mirasol system for WB could make RBC transfusion safer. The benefit of any new technology for processing blood components must be weighed against the negative effects on the quality of the blood product. This study is an in vitro paired evaluation of quality parameters of RBCs derived from WB treated with the Mirasol system for WB method and stored for 21 days at $1-6^{\circ} \mathrm{C}$.

\section{Methods}

A total of 61 individuals each donated 2 units of WB for this study: the first to be treated with the Mirasol system for WB (test unit) and the second to be left untreated (control unit). The units were collected at least 8 weeks apart.

Fresh WB units were collected in $63 \mathrm{~mL}$ of anticoagulant citrate phosphate dextrose with a target collection volume of $470 \mathrm{~mL}$. The WB units used to prepare test articles were transferred into an illumination bag (attached to a storage bag; Terumo BCT). Riboflavin solution $(35 \mathrm{~mL}$ of $500 \mu \mathrm{M}$ riboflavin in $0.9 \% \mathrm{NaCl}$; Terumo $\mathrm{BCT}$ ) was added to all test units and they were exposed to a target dose of $80 \mathrm{~J} / \mathrm{mL}_{\mathrm{RBC}} \mathrm{UV}$ light in the Mirasol Illuminator. All test units were treated within $6 \mathrm{~h}$ of collection. RBCs were separated from both Mirasol-treated test units and untreated control units and resuspended in $100 \mathrm{~mL}$ of AS-3, and leukoreduced through an RCM1 filter (Pall). The completion of RBC preparation for storage occurred within $8 \mathrm{~h}$ of collection. All test and control RBC units were stored at $1-6^{\circ} \mathrm{C}$ in AS-3 for 21 days.

Samples were removed postcollection (all non-leukoreduced WB units), posttreatment (non-leukoreduced treated WB product), and on day 0 and day 21 (leukoreduced RBCs, separated from treated and control WB and stored in AS-3).

To evaluate haematocrit and $\mathrm{Hb}$ and to quantify $\mathrm{RBCs}$ and WBCs, the automated haematology cell counting system Coulter ACT-Diff Haematology Analyser (Beckman Coulter) was used according to the manufacturer's instructions. The total $\mathrm{Hb}$ per unit was calculated by multiplying the $\mathrm{Hb}$ concentration by the unit volume. The RBC recovery following the leukoreduction procedure was calculated, taking into account the loss of volume due to sampling. Residual WBCs were quantified using the LeukoCOUNT flow cytometry kit (Becton Dickinson Biosciences).

Siemens RapidLab 1,265 blood gas analysers (Siemens Healthcare) were used according to the manufacturer's instructions to measure $\mathrm{pH}$, blood gases, and metabolites. On day 21 , the potassium $\left(\left[\mathrm{K}^{+}\right]\right)$levels fell outside the measurement range of the analyser; therefore, the samples were diluted $1: 5$ and the final concentration was calculated taking the dilution into account.

The protein concentration was measured using the Pierce BCA Protein Assay (Thermo Fisher Scientific) as per the manufacturer's instructions. For a subset of 11 paired units, oxyhaemoglobin dissociation curves (ODCs) were generated on day 1 and day 22 using a Hemox Analyser (TCS Scientific Corporation).

To measure adenosine triphosphate (ATP), the ATPlite assay kit (PerkinElmer Inc.), based on the reaction of luciferase with Dluciferin and ATP, was used. The RBC samples were diluted in 


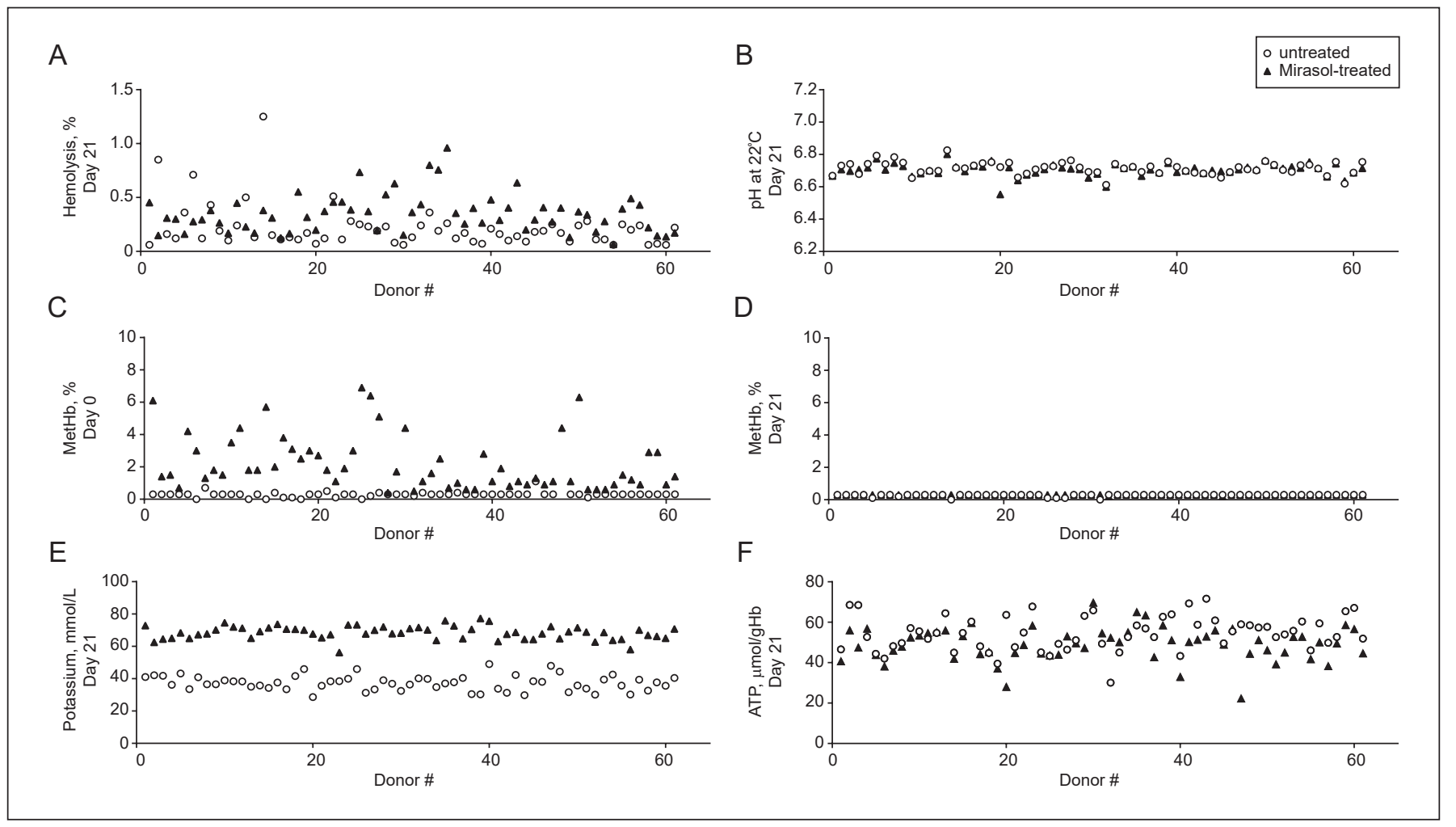

Fig. 1. In vitro characteristics of paired units of RBCs derived from Mirasol-treated and control WB collected from 61 donors. A Haemolysis values for paired RBC units derived from donors 1 through 61 assayed on day 21. B pH values for paired RBC units derived from donors 1 through 61, day 21. C Methaemoglobin values for

$0.9 \%$ saline to a $30-40 \%$ haematocrit range to ensure complete extraction. ATP was extracted from the RBC samples using $0.73 \mathrm{M}$ of trichloroacetic acid (TCA) in $0.1 \mathrm{M}$ tris-acetate buffer at $\mathrm{pH} 8.38$ 8.40. The TCA extraction was performed instead of using the manufacturer's cell lysis buffer procedure to negate the quenching interference demonstrated with solutions containing free $\mathrm{Hb}$.

Assays for quantifying 2.3-diphosphoglycerate (2.3-DPG) were performed at an external facility using a method similar to the one described by Lowry et al. [17]. The total $\mathrm{Hb}$ was first obtained from the Coulter ACT-Diff Haematology Analyser measurements to enable the calculation of $2.3-\mathrm{DPG} \mu \mathrm{mol} / \mathrm{g} \mathrm{Hb}$. The RBCs were lysed using ice-cold $0.6 \mathrm{M}(4 \%)$ perchloric acid, frozen at $-80^{\circ} \mathrm{C}$ and shipped to the external site for 2.3-DPG analysis. Testing of regeneration of 2.3 DPG was done on the day $21 \mathrm{RBC}$ samples only, using a rejuvenation solution (100 mM sodium pyruvate, $100 \mathrm{mM}$ inosine, $5 \mathrm{mM}$ adenine, $70 \mathrm{mM}$ dibasic sodium phosphate, $29 \mathrm{mM}$ monobasic sodium phosphate). After rejuvenation, samples were prepared in the same manner as were non-rejuvenated samples.

Crossmatching was performed in an ID-Micro Typing System (Ortho-Clinical Diagnostics) according to a standard antihuman globulin technique [18] and the manufacturer's instructions. Plasma for autologous crossmatching was obtained from each unit of $\mathrm{WB}$, and aliquots were frozen and stored until the time of crossmatch.

For a separate study of $\left[\mathrm{K}^{+}\right]$and MetHb concentration in Mirasol-treated versus gamma-irradiated RBCs, 15 fresh WB units were collected in $63 \mathrm{~mL}$ of citrate phosphate dextrose, with a target collection volume of $450 \mathrm{~mL}$. Seven units assigned to gamma irradiation were leukoreduced, processed into RBCs as described

paired RBC units derived from donors 1 through 61, day 0. D Methaemoglobin values for paired RBC units derived from donors 1 through 61, day 21. E Potassium values for paired units derived from donors 1 through 61, day 21. F ATP values for paired units derived from donors 1 through 61, day 21.

previously, gamma irradiated (25 Gy) at Bonfils Blood Center (Denver, CO, USA), and then returned to Terumo BCT for storage and sampling. Eight units were Mirasol-treated and then leukoreduced and processed into RBCs. Units were stored as RBCs in AS-3 at $1-6^{\circ} \mathrm{C}$ for 21 days. The samples were collected at different time points as indicated and were assayed using the Siemens RapidLab 1,265 blood gas analyser (Siemens Healthcare).

\section{Statistical Analysis}

The sample size of at least 60 paired units was used to provide $95 \%$ confidence that $95 \%$ of all the sampled population would meet the test criteria of haemolysis $\leq 1 \%, \mathrm{pH} \geq 6.2$, and crossmatch compatibility provided that no failures were recorded. For quantitative data, the results for test and control $\mathrm{RBC}$ units were compared at each time point using the Student paired $t$ test. For a statistical comparison of $\left[\mathrm{K}^{+}\right]$in Mirasol-treated versus gamma-irradiated RBCs units over time, a two-way ANOVA was used. $p<0.05$ was considered statistically significant.

\section{Results}

This study was designed to directly compare RBCs derived from Mirasol-treated and untreated WB using a panel of in vitro parameters. Haemolysis increased through storage and was higher in Mirasol-treated units compared to control units $(p<0.001)$. However, the hae- 
Table 1. In vitro parameters of treated and control whole blood and red blood cells derived thereof

\begin{tabular}{|c|c|c|c|c|c|c|}
\hline & $\begin{array}{l}\text { Control WB } \\
\text { collection }\end{array}$ & $\begin{array}{l}\text { Test WB at } \\
\text { collection, } \\
\text { pretreatment }\end{array}$ & $\begin{array}{l}\text { Control RBCs } \\
\text { on day } 0\end{array}$ & $\begin{array}{l}\text { Test RBCs } \\
\text { on day } 0\end{array}$ & $\begin{array}{l}\text { Control RBCs } \\
\text { on day } 21\end{array}$ & $\begin{array}{l}\text { Test RBCs } \\
\text { on day } 21\end{array}$ \\
\hline Hct, \% & $\begin{array}{l}35.5 \pm 3.3 \\
(28.7-40.9)\end{array}$ & $\begin{array}{l}35.6 \pm 3.2 \\
(29.6-41.7)\end{array}$ & $\begin{array}{l}57.1 \pm 2.9 \\
(48.9-61.7)\end{array}$ & $\begin{array}{l}56.9 \pm 2.6 \\
(50.9-61.4)\end{array}$ & $\begin{array}{l}57.7 \pm 2.7 \\
(51.4-62.9)\end{array}$ & $\begin{array}{l}56.7 \pm 2.9^{*} \\
(50.7-63.0)\end{array}$ \\
\hline $\mathrm{pH}_{22 \mathrm{C}}$ & $\begin{array}{l}7.25 \pm 0.03 \\
(7.18-7.30)\end{array}$ & $\begin{array}{l}7.25 \pm 0.02 \\
(7.19-7.31)\end{array}$ & $\begin{array}{l}7.00 \pm 0.04 \\
(6.91-7.06)\end{array}$ & $\begin{array}{l}7.00 \pm 0.03 \\
(6.91-7.09)\end{array}$ & $\begin{array}{l}6.71 \pm 0.04 \\
(6.61-6.83)\end{array}$ & $\begin{array}{l}6.70 \pm 0.04^{*} \\
(6.55-7.80)\end{array}$ \\
\hline Haemolysis, \% & $\begin{array}{l}0.17 \pm 0.06 \\
(0.12-0.57)\end{array}$ & $\begin{array}{l}0.17 \pm 0.04 \\
(0.12-0.38)\end{array}$ & $\begin{array}{l}0.07 \pm 0.01 \\
(0.05-0.09)\end{array}$ & $\begin{array}{l}0.08 \pm 0.05 \\
(0.06-0.44)\end{array}$ & $\begin{array}{l}0.21 \pm 0.20 \\
(0.06-1.25)\end{array}$ & $\begin{array}{l}0.35 \pm 0.18^{*} \\
(0.07-0.96)\end{array}$ \\
\hline Hb concentration, g/dL & $\begin{array}{l}12.1 \pm 1.2 \\
(9.6-14.5)\end{array}$ & $\begin{array}{l}12.1 \pm 1.3 \\
(9.3-14.3)\end{array}$ & $\begin{array}{l}19.1 \pm 1.1 \\
(16.6-21.6)\end{array}$ & $\begin{array}{l}19.1 \pm 1.2 \\
(16.3-21.2)\end{array}$ & $\begin{array}{l}19.4 \pm 1.1 \\
(17.2-21.7)\end{array}$ & $\begin{array}{l}19.2 \pm 1.2 \\
(16.5-21.1)\end{array}$ \\
\hline MetHb, \% & $\begin{array}{l}0.8 \pm 0.5 \\
(0.1-1.8)\end{array}$ & $\begin{array}{l}0.6 \pm 0.4^{*} \\
(0.1-1.7)\end{array}$ & $\begin{array}{l}0.3 \pm 0.2 \\
(0.00-1.10)\end{array}$ & $\begin{array}{l}2.2 \pm 1.7^{*} \\
(0.4-6.9)\end{array}$ & $\begin{array}{l}0.3 \pm 0.1 \\
(0.0-0.3)\end{array}$ & $\begin{array}{l}0.3 \pm 0.0^{*} \\
(0.2-0.3)\end{array}$ \\
\hline $\mathrm{MCV}, \mathrm{fL}$ & $\begin{array}{l}87.0 \pm 6.8 \\
(71.3-101.3)\end{array}$ & $\begin{array}{l}88.2 \pm 6.7^{*} \\
(69.7-101.6)\end{array}$ & $\begin{array}{l}87.6 \pm 6.7 \\
(71.7-101.1)\end{array}$ & $\begin{array}{l}88.7 \pm 6.7 \\
(70.2-102.3)\end{array}$ & $\begin{array}{l}88.4 \pm 6.7 \\
(73.3-103.6)\end{array}$ & $\begin{array}{l}88.4 \pm 6.9 \\
(69.6-104.5)\end{array}$ \\
\hline $\mathrm{K}^{+}, \mathrm{mmol} / \mathrm{L}$ & $\begin{array}{l}3.24 \pm 0.21 \\
(2.70-3.64)\end{array}$ & $\begin{array}{l}3.15 \pm 0.19^{*} \\
(2.77-3.60)\end{array}$ & $\begin{array}{l}2.08 \pm 0.37 \\
(1.27-3.03)\end{array}$ & $\begin{array}{l}2.23 \pm 0.34^{*} \\
(1.53-3.06)\end{array}$ & $\begin{array}{l}37.35 \pm 4.61 \\
(28.65-49.04)\end{array}$ & $\begin{array}{l}68.42 \pm 4.12^{*} \\
(56.20-77.31)\end{array}$ \\
\hline $\mathrm{Na}^{+}, \mathrm{mmol} / \mathrm{L}$ & $\begin{array}{l}155.2 \pm 2.1 \\
(150.0-160.3)\end{array}$ & $\begin{array}{l}154.9 \pm 1.9 \\
(151.2-160.2)\end{array}$ & $\begin{array}{l}142.9 \pm 1.7 \\
(139.50-148.60)\end{array}$ & $\begin{array}{l}142.4 \pm 1.4 \\
(140.0-146.9)\end{array}$ & $\begin{array}{l}117.6 \pm 3.2 \\
(108.9-123.7)\end{array}$ & $\begin{array}{l}88.2 \pm 2.9^{*} \\
(82.30-96.50)\end{array}$ \\
\hline 2,3-DPG, $\mu \mathrm{mol} / \mathrm{gHb}$ & $\begin{array}{l}12.2 \pm 4.1 \\
(3.9-31.0)\end{array}$ & $\begin{array}{l}13.9 \pm 4.4^{*} \\
(6.6-24.0)\end{array}$ & $\begin{array}{l}12.0 \pm 3.1 \\
(0.00-18.4)\end{array}$ & $\begin{array}{l}13.0 \pm 3.2^{*} \\
(7.2-21.9)\end{array}$ & NR & NR \\
\hline $\begin{array}{l}\text { 2,3-DPG regenerated, } \\
\mu \mathrm{mol} / \mathrm{gHb}\end{array}$ & NA & NA & $\mathrm{NA}$ & NA & $\begin{array}{l}13.8 \pm 4.6 \\
(0.0-20.9)\end{array}$ & $\begin{array}{l}15.0 \pm 4.6 \\
(3.13-24.04)\end{array}$ \\
\hline $\mathrm{ATP}$ in $\mathrm{RBC}, \mu \mathrm{mol} / \mathrm{gHb}$ & $\begin{array}{l}4.31 \pm 0.83 \\
(1.51-5.95)\end{array}$ & $\begin{array}{l}4.34 \pm 0.52 \\
(2.99-5.61)\end{array}$ & $\begin{array}{l}4.50 \pm 0.84 \\
(1.59-6.22)\end{array}$ & $\begin{array}{l}4.62 \pm 0.59 \\
(3.32-6.05)\end{array}$ & $\begin{array}{l}5.50 \pm 0.80 \\
(3.46-7.29)\end{array}$ & $\begin{array}{l}4.90 \pm 0.87^{*} \\
(2.10-6.89)\end{array}$ \\
\hline $\mathrm{pCO}_{2}, \mathrm{~mm} \mathrm{Hg}$ & $\begin{array}{l}85.6 \pm 8.0 \\
(68.0-104.3)\end{array}$ & $\begin{array}{l}84.2 \pm 7.4 \\
(69.2-105.4)\end{array}$ & $\begin{array}{l}78.3 \pm 6.5 \\
(61.6-93.4)\end{array}$ & $\begin{array}{l}68.6 \pm 5.7^{*} \\
(58.1-84.6)\end{array}$ & $\begin{array}{l}123.0 \pm 12.5 \\
(100.5-148.9)\end{array}$ & $\begin{array}{l}122.7 \pm 10.7 \\
(100.7-144.5)\end{array}$ \\
\hline $\mathrm{pO}_{2}, \mathrm{~mm} \mathrm{Hg}$ & $\begin{array}{l}26.9 \pm 5.4 \\
(18.9-45.8)\end{array}$ & $\begin{array}{l}29.2 \pm 5.4^{*} \\
(21.7-43.3)\end{array}$ & $\begin{array}{l}33.5 \pm 6.0 \\
(23.5-56.8)\end{array}$ & $\begin{array}{l}32.8 \pm 5.8 \\
(22.8-47.7)\end{array}$ & $\begin{array}{l}41.1 \pm 5.9 \\
(31.0-59.6)\end{array}$ & $\begin{array}{l}36.5 \pm 4.6^{*} \\
(27.9-47.7)\end{array}$ \\
\hline $\mathrm{HCO}_{3}{ }^{-}, \mathrm{mmol} / \mathrm{L}$ & $\begin{array}{l}15.0 \pm 1.1 \\
(12.8-18.2)\end{array}$ & $\begin{array}{l}15.1 \pm 1.0 \\
(13.1-17.0)\end{array}$ & $\begin{array}{l}7.8 \pm 0.9 \\
(5.7-9.4)\end{array}$ & $\begin{array}{l}7.4 \pm 0.9^{*} \\
(5.4-9.1)\end{array}$ & $\begin{array}{l}6.1 \pm 0.9 \\
(3.9-7.6)\end{array}$ & $\begin{array}{l}5.8 \pm 0.9^{*} \\
(2.9-7.3)\end{array}$ \\
\hline Glucose, $\mathrm{mmol} / \mathrm{L}$ & $\begin{array}{l}19.0 \pm 1.8 \\
(15.2-24.1)\end{array}$ & $\begin{array}{l}19.4 \pm 1.3 \\
(16.9-25.5)\end{array}$ & $\begin{array}{l}27.8 \pm 2.3 \\
(23.6-31.6)\end{array}$ & $\begin{array}{l}27.6 \pm 1.6 \\
(23.7-30.2)\end{array}$ & $\begin{array}{l}19.9 \pm 1.7 \\
(16.4-25.3)\end{array}$ & $\begin{array}{l}19.1 \pm 1.9^{*} \\
(12.7-23.4)\end{array}$ \\
\hline Lactate, $\mathrm{mmol} / \mathrm{L}$ & $\begin{array}{l}2.80 \pm 0.79 \\
(1.38-5.27)\end{array}$ & $\begin{array}{l}2.46 \pm 0.66^{*} \\
(1.32-5.01)\end{array}$ & $\begin{array}{l}2.11 \pm 0.46 \\
(1.03-3.51)\end{array}$ & $\begin{array}{l}2.00 \pm 0.44 \\
(1.27-3.51)\end{array}$ & $\begin{array}{l}15.28 \pm 2.11 \\
(11.14-20.18)\end{array}$ & $\begin{array}{l}15.53 \pm 2.52 \\
(10.53-20.75)\end{array}$ \\
\hline
\end{tabular}

Values reported are the mean \pm 1 SD (range) for $n=61$ paired units. ${ }^{*}$ Significantly different from paired control at the same time point, $p<0.05$, Student $t$ test. Marked differences were observed for several measured values between WB postcollection and RBC day 0 samples due to the removal of plasma after centrifugation and the subsequent addition of AS-3 storage solution, as well as the loss of RBC volume from leukoreduction and sample removal. WB, whole blood; RBC, red blood cell; Hct, haematocrit; Hb, haemoglobin; $\mathrm{MetHb}$, methaemoglobin; MCV, mean corpuscular volume; $\mathrm{K}^{+}$, potassium; $\mathrm{Na}^{+}$, sodium; 2,3-DPG, 2,3-bisphosphoglyceric acid; NR, not reported, most values below limit of detection; NA, not applicable; ATP, adenosine triphosphate; $\mathrm{pCO}_{2}$, partial pressure of carbon dioxide; $\mathrm{pO}_{2}$, partial pressure of oxygen; $\mathrm{HCO}_{3}^{-}$, bicarbonate.

molysis remained below $1 \%$ in all units, with a mean of $0.35 \%$ for Mirasol-treated units after 21 days of storage. One unit in the control group had haemolysis $>1 \%$; no Mirasol-treated group units were above this value (Fig. 1A). European guidelines for haemolysis $(\leq 0.8 \%)$ were exceeded in 3 control units and 1 test unit. The $\mathrm{pH}$ value decreased through storage but remained above 6.2 in all samples (Fig. 1B).

The FDA recommendation for leukoreduction performance specifies a residual WBC count of $\leq 5 \times 10^{6}$ per unit and at least $85 \% \mathrm{RBC}$ recovery after leukoreduction, with $95 \%$ confidence that at least $95 \%$ of the population meets or exceeds the specification [19]. These FDA criteria were met in all Mirasol-treated units; the mean residual WBC count per unit was $4.6 \times 10^{5} \pm 0.3 \times 10^{6}$ (min. $2.7 \times 10^{4}$, max. $\left.1.7 \times 10^{6}\right)$ and RBC recovery after leukoreduction was $90 \pm 2 \%$ ( $\min .85$, max. 94). For untreated units, the residual WBC count was $2.4 \times 10^{5} \pm 0.6 \times 10^{6}$ per unit (min. limit of detection, max. $1.3 \times 10^{6}$ ) and $\mathrm{RBC}$ recovery after leukoreduction was $89 \pm 4 \%$ (min. 76, max. 105). 
The European guidelines require a residual WBC count of $\leq 1 \times 10^{6}$ per unit. Four treated units and 1 untreated unit would fail this criterion. The leukoreduction filter used in this study is intended for the US market where the residual WBC count is balanced with $\mathrm{RBC}$ mass recovery. The leukocyte depletion is less efficient in the treated units but still well within the US specifications. It should be pointed out that the de facto risk associated with residual WBCs should be smaller with RBCs derived from treated WB, since PRT inactivates WBCs at least as efficiently as gamma irradiation, as demonstrated by Fast et al. [10]

Methaemoglobin levels give an indication of the oxidative state of the cell. UV light exposure converts a small portion of the $\mathrm{RBC} \mathrm{Hb}$ to MetHb, which is then rapidly converted back to oxyhaemoglobin during storage. On day 0 , MetHb levels were higher in the Mirasol-treated units than in their untreated control counterparts (Fig. 1C; Table 1), but by day 21 the MetHb levels in the Mirasoltreated units were similar to control units (Fig. 1D). To enable a more detailed analysis of changes in MetHb levels over time, we performed a separate study of $n=8 \mathrm{RBC}$ units derived from Mirasol-treated WB where MetHb levels were assayed postcollection, posttreatment, and on days $1,2,3,7,14$, and 21 . That study showed that by day 1 , MetHb levels in the RBC units returned to values below those assayed in WB postcollection (Table 2).

After 21 days of storage, $\left[\mathrm{Na}^{+}\right]$was significantly lower in Mirasol-treated samples compared to control samples $(p<0.001)$. Conversely, $\left[\mathrm{K}^{+}\right]$increased throughout storage of RBCs and more so in Mirasol-treated units than in control units (Fig. 1E). The mean $\left[\mathrm{K}^{+}\right]$on day 21 was higher in Mirasol-treated units than in control units $(p<$ 0.001 ; Table 1). The high $\left[\mathrm{K}^{+}\right]$observed in Mirasol-treated RBCs is similar to what has been observed in gammairradiated products after 28 days of storage $[20,21]$ and in conventional RBCs stored for 42 days [22]. To accurately compare how $\left[\mathrm{K}^{+}\right]$changes over time in Mirasoltreated RBC units versus gamma-irradiated RBC units under similar conditions, Terumo BCT performed a sideby-side comparison. As shown in Figure $2,\left[\mathrm{~K}^{+}\right]$increases in both Mirasol-treated $(n=8)$ and gamma-irradiated $\mathrm{RBC}$ units $(n=7)$ during storage, and $\left[\mathrm{K}^{+}\right]$was higher in Mirasol-treated RBC units as compared to gamma-irradiated RBC units.

The phosphate 2.3-DPG binds to $\mathrm{Hb}$, facilitating oxygen release. The control units had a higher 2.3-DPG concentration on day 0 than the Mirasol-treated units $(p=$ 0.02 ), with a significant difference between the mean values of the test and control groups at the time of collection (fresh, untreated WB; $p=0.04$ ), suggesting a large variability independent of treatment. The 2.3-DPG levels were depleted in both Mirasol-treated and control RBCs after 21 days of refrigerated storage, with most samples below the level of detection for the assay. This is a well-
Table 2. Percent methaemoglobin in red blood cells derived from Mirasol-treated WB

\begin{tabular}{ll}
\hline Days in storage & $\begin{array}{l}\text { \% methaemoglobin in Mirasol-treated } \\
\text { RBCs, } n=8\end{array}$ \\
\hline 0 (pretreatment) & $0.8 \pm 0.4(0.2-1.2)$ \\
0 (posttreatment) & $1.4 \pm 0.6(0.7-2.3)$ \\
1 & $0.2 \pm 0.2(0-0.6)$ \\
2 & $0.2 \pm 0.1(0-0.3)$ \\
3 & $0.3 \pm 0(0.3-0.3)$ \\
7 & $0.3 \pm 0(0.3-0.3)$ \\
14 & $0.3 \pm 0(0.3-0.3)$ \\
21 & $0.3 \pm 0(0.2-0.3)$ \\
\hline
\end{tabular}

Values are the mean \pm SD (range). RBCs, red blood cells.

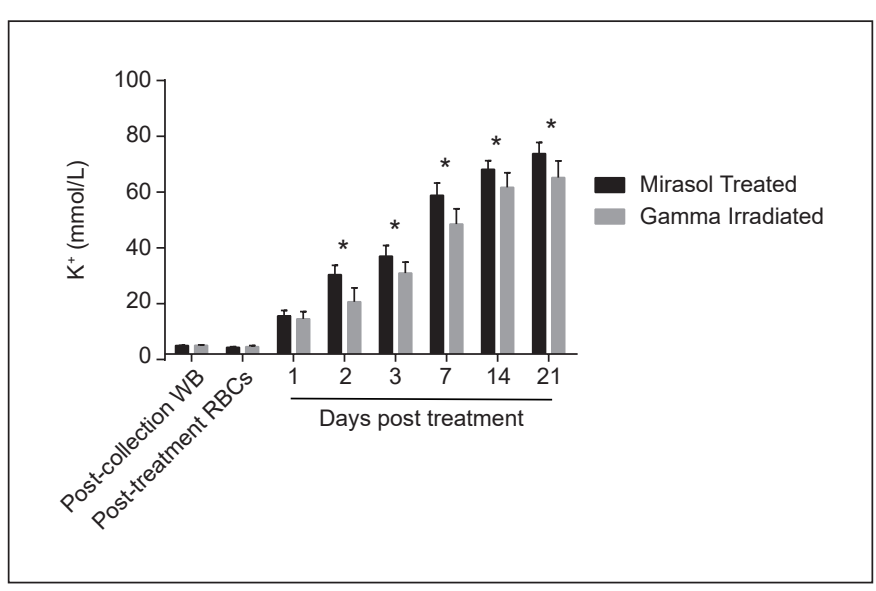

Fig. 2. Potassium concentration in Mirasol-treated versus gammairradiated RBCs over time. Mean values of extracellular $\left[\mathrm{K}^{+}\right]$in RBCs derived from Mirasol-treated WB $(n=8)$ and RBCs derived from untreated WB and the gamma irradiated RBCs $(n=7)$. Error bars represent standard deviations. ${ }^{*} p<0.05$.

known effect of RBC storage [23]. Samples from 21-day stored treated RBCs and control RBCs were incubated with rejuvenation solution to mimic the restoration of 2.3-DPG that has been shown to take place in vivo [24, 25]. There was no significant difference between the values of regenerated 2.3-DPG in Mirasol-treated units and control units on day 21 ( $p=0.32$; Table 1$)$.

Over the course of storage, $\mathrm{pCO}_{2}$ and $\mathrm{pO}_{2}$ increased, and the concentration of $\mathrm{HCO}_{3}$ decreased, for both test and control arms. Levels of glucose decreased over the course of storage, whereas levels of lactate increased (Table 1).

Mean ATP levels varied between 4.3 and $5.5 \mu \mathrm{mol} /$ $\mathrm{gHb}$. On day 0 , the treated sample average values did not differ significantly compared to the controls $(p=0.26$; Table 1). After 21 days, the ATP concentrations were significantly lower in Mirasol-treated units $(p<0.001$; Table 1; Fig. 1F). 
Fig. 3. Representative oxygen dissociation curve for Mirasol-treated versus control RBCs. Oxygen dissociation curves for RBCs derived from 1 unit of Mirasol-treated WB after storage for 1 day and 22 days at $4{ }^{\circ} \mathrm{C}$, and RBCs derived from untreated WB from 1 unit from the same donor and stored for 1 day and 22 days. p50, the partial pressure of oxygen when $\mathrm{Hb}$ is $50 \%$ oxygenated.

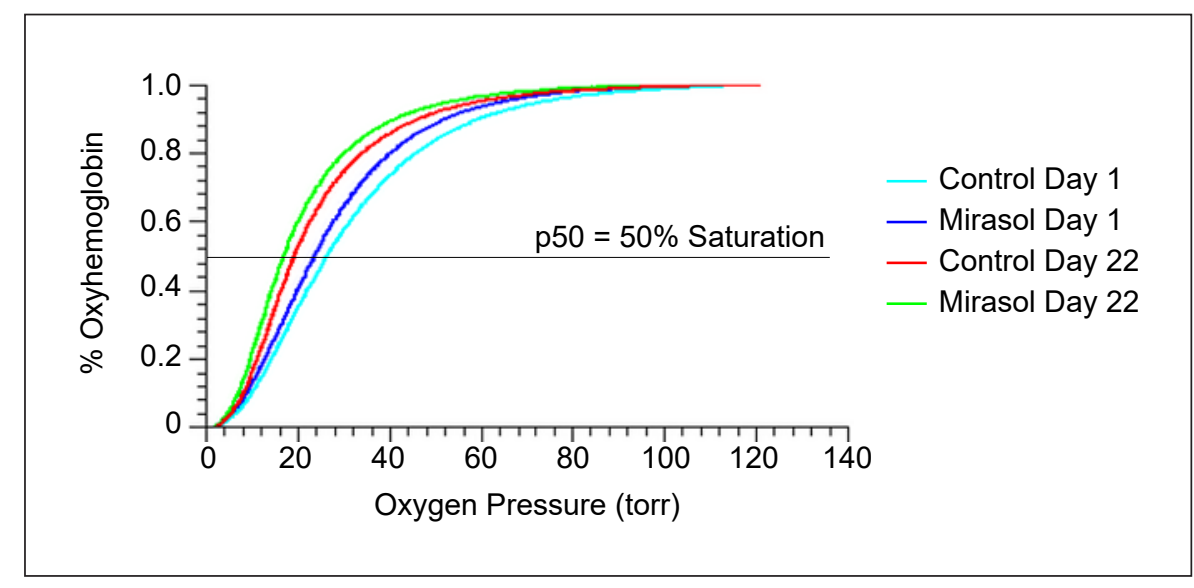

To specifically measure whether the oxygen transporting function of RBCs was affected by Mirasol treatment, ODCs were generated for a subset of the paired units $(n=11)$ on day 1 and day 22 using a Hemox Analyser (TCS Scientific). Figure 3 shows representative ODCs for a Mirasol-treated RBC unit and a paired untreated control unit on day 1 and day 22, demonstrating that the ODC for the treated RBCs maintained the same sigmoidal shape as those for controls and was slightly left-shifted relative to the controls, as reflected in statistically significantly lower p50 (the partial pressure of oxygen at which $\mathrm{Hb}$ is $50 \%$ oxygenated) values for Mirasol-treated RBCs compared to control RBCs ( $p=0.003$ at both time points). The mean paired difference in $\mathrm{p} 50$ (the mean of all the differences in percentage between Mirasol-treated units versus paired controls) on day 1 and day 22 was $7.1 \pm 6.5 \%$ and $5.0 \pm 6.4 \%$, respectively.

Crossmatching is performed to ensure that the blood recipient does not have antibodies against the donor's blood. If the RBC surface is structurally changed, there could be blood type-independent binding of immunoglobulin $\mathrm{G}$ autoantibodies and/or alloantibodies to the RBC surface. All units $(n=61)$ in this paired study were crossmatch compatible, indicating that there was no antibody binding to the RBCs when plasma was exposed to autologous RBCs (data not shown).

\section{Discussion}

This study evaluated the quality of RBCs stored for 21 days derived from WB treated with the Mirasol system for WB. This study demonstrates that RBCs derived from Mirasol-treated WB do not differ from control units after 21 days of storage in terms of the most crucial measurements of RBC integrity and function and that, with a few exceptions, the value of in vitro parameters are similar to those of conventional RBCs and within normal storage parameters.

RBCs from Riboflavin/UV-Treated WB
The first donation from each donor was always Mirasol-treated in this study whereas the second donation was always designated as a control. Prior to treatment, the units in the control group and the test group did not differ significantly in terms of haematocrit, $\mathrm{pH}$, haemolysis, and $\mathrm{Hb}$. Haemolysis increased throughout storage and was higher in the Mirasol-treated RBC units, but no treated units exceeded the FDA guideline of haemolysis $\leq 1 \%$ after 21 days of storage. However, the European guideline of $\leq 0.8 \%$ was exceeded in 3 control units and 1 test unit. The $\mathrm{pH}$ decreased slightly but remained well above 6.2 in all samples. Furthermore, all units were crossmatch-compatible with autologous plasma, suggesting that Mirasol treatment does not lead to structural changes in the RBC surface that would give rise to binding of plasma proteins or antibodies. Mirasol treatment is unlikely to have a clinically important effect on the oxygen-transporting function of the RBCs, since ODCs were similar in shape and differences in p50 were small. It should be noted that some parameters displayed statistically significant differences between test and control units for mean postcollection values, before Mirasol treatment, and these differences persisted following Mirasol treatment and processing into treated or untreated RBCs. This suggests an intra-donor variability effect.

In vitro parameter levels do not always predict in vivo clinical performance. In the clinical feasibility study IMPROVE II, a statistically significant positive correlation was found between 24 -h RBC recovery in vivo and endof-storage ATP concentration in vitro, but not for any other measured in vitro parameters [26]. The ATP levels of the 21-day-old RBCs derived from Mirasol-treated WB in the IMPROVE II study $(4.4 \pm 1.13 \mu \mathrm{mol} / \mathrm{gHb})$ were similar to the ATP levels reported in the present study $(4.9 \pm 0.87 \mu \mathrm{mol} / \mathrm{gHb})$, correlating with a clinically adequate 24 -h RBC recovery in vivo of $82.5 \pm 3.9 \%$ [26], exceeding the FDA's criterion ( $\geq 75 \%)$ [27].

The most notable differences between Mirasol-treated $\mathrm{RBCs}$ and controls were for the parameters MetHb and 
$\left[\mathrm{K}^{+}\right]$. The separate study $(n=8$; Table 2$)$ demonstrated that MetHb levels in Mirasol-treated units returned to normal levels within $24 \mathrm{~h}$ of treatment. Even the relatively high MetHb levels on day 0 were well below the established levels of clinical significance [28].

After 21 days of storage, $\left[\mathrm{K}^{+}\right]$in $\mathrm{RBCs}$ derived from Mirasol-treated WB was higher than in untreated RBCs. However, the difference compared to gamma-irradiated RBC units, albeit statistically significant, was small. Increased $\left[\mathrm{K}^{+}\right]$in blood products following storage may not be predictive of a clinical effect on serum $\left[\mathrm{K}^{+}\right]$[29]. Because of rapid dilution upon transfusion, redistribution of $\left[\mathrm{K}^{+}\right]$into cells, and excretion, hyperkalaemia is a rare transfusion event [30]. In fact, hypokalaemia is a more frequent complication of RBC transfusion than hyperkalaemia [31]. The clinical effects of a higher extracellular $\left[\mathrm{K}^{+}\right]$in blood products are likely to be negligible for most patients but could be influenced by patient factors and the mode of blood administration [32].

In IMPROVE II, RBCs collected, treated, processed, and stored under the same conditions as the test units in this study maintained an adequate $24-\mathrm{h} \mathrm{RBC}$ recovery in vivo $(82.5 \pm 3.9)$ and a $17 \%$ difference in area-under-thecurve (AUC) of RBC survival as compared to conventional RBCs [26]. This suggests that despite some in vitro differences observed between RBCs derived from Mirasol-treated WB and conventional RBCs, in vivo recovery and survival are well within ranges associated with sufficient clinical performance. Mirasol-treated RBCs have a shorter shelf life compared to standard of care products ( 21 vs. 42 days). Studies using simulation models in Canada [33] and Spain [34] have determined that shortening the maximum shelf life for RBCs to 21 [33] or 28 [34] days, respectively, would have only modest impacts on outdate and shortage rates. Possibly apart from the rarest blood groups, the impact of a shortened shelf life may be offset by gains in blood safety.

In conclusion, the in vitro data reported here suggest that RBCs derived from Mirasol-treated WB are suitable for transfusion throughout 21 days of storage. The add-

\section{Statement of Ethics}

Institutional Review Board and US Army Medical Research and Materiel Command (USAMRMC) Human Research Protections Office approval was obtained for collecting blood from healthy donors according to standard blood collection procedures.

\section{Disclosure Statement}

The views expressed in this manuscript are the authors' own views and do not represent an official position of their institutions or the organisations funding this research.

All authors except R.P.G. are employees of Terumo BCT, the manufacturer of the Mirasol technology. R.P.G. is a former employee of Terumo BCT and is under a consulting agreement with Terumo BCT.

\section{Funding Sources}

This work was supported by the Terumo BCT (formerly Caridian BCT Biotechnologies, LLC) Department of Defense (DOD) Awards W81XWH-09-2-0100 and W81XWH-13-C-0160. The US Army Medical Research Acquisition Activity (Fort Detrick, MD, USA) is the awarding and administering acquisition office. The opinions or assertions contained herein are the private views of the author and are not to be construed as official or as reflecting the views of the Department of the Army or the Department of Defense.

\section{Author Contributions}

S.K.D., H.L.R, R.P.G, and S.M. designed the research; S.K.D., N.H., E.J.G., M.T, and S.W. performed the research and collected data; L.Y.D. wrote the manuscript; L.Y.D, S.K.D., S.Y., H.L.R, N.H., E.J.G, M.T., S.W., and S.M. analysed and interpreted the data; all authors critically reviewed and revised the manuscript, and approved the submitted and final versions. ed benefits of reducing the risk of TTIs and decreasing the risk of deleterious immune reactions, including TAGvHD may outweigh a shorter shelf life and the modest impact on RBC quality. The Mirasol system is presently the only technology that provides the means of obtaining pathogen reduction for all components, including platelets, plasma, RBCs, and WB, within the same platform.

\section{Acknowledgements}

The authors thank Dr. Jeffrey McCullough (Emeritus Professor, University of Minnesota) for his invaluable assistance in the writing of this manuscript. The authors thank Dr. Heather F. Pidcoke for critically reviewing the manuscript.

References DOI: $10.1159 / 000495257$
1 Franceschi S, Dal Maso L, La Vecchia C. Trends in incidence of AIDS associated with transfusion of blood and blood products in Europe and the United States, 1985-93. BMJ. 1995 Dec;311(7019):1534-6.

2 Jaczko GB. The 2010 radiation source protection and security task force report. Washington: US Nuclear Regulatory Commission; 2010.

3 Kumar V, Lockerbie O, Keil SD, Ruane PH, Platz MS, Martin CB, et al. Riboflavin and UV-light based pathogen reduction: extent and consequence of DNA damage at the molecular level. Photochem Photobiol. 2004 JulAug;80(1):15-21.

4 Keil SD, Rapaport R, Doane SK, Young R, Marschner S, Campbell TB. Viral reduction of intracellular HIV using the Mirasol system for whole blood [poster abstract]. Vox Sang. 2012;103:144. 
5 Doane S, Keil SD, Gilmour DI, Reddy H, Wilkinson S, Hovenga N, et al. Treatment of whole blood with riboflavin and UV light: effectiveness against clinically relevant bacterial contamination. Transfusion. 2013;53:203A.

6 Owusu-Ofori S, Kusi J, Owusu-Ofori A, Freimanis G, Olver C, Martinez CR, Wilkinson S Mundt JM, Keil SD, Goodrich RP, Allain JP: Treatment of whole blood (WB) with riboflavin and UV light: impact on malaria parasite viability and WB storage. Shock. 2015 Aug; 44(suppl 1):33-8.

7 Tonnetti L, Thorp AM, Reddy HL, Keil SD, Goodrich RP, Leiby DA. Riboflavin and ultraviolet light reduce the infectivity of Babesia microti in whole blood. Transfusion. 2013 Apr;53(4):860-7.

8 Tonnetti L, Thorp AM, Reddy HL, Keil SD, Goodrich RP, Leiby DA. Evaluating pathogen reduction of Trypanosoma cruzi with riboflavin and ultraviolet light for whole blood. Transfusion. 2012 Feb;52(2):409-16.

9 Tonnetti L, Thorp AM, Reddy HL, Keil SD, Doane S, Goodrich RP, et al. Validating the Mirasol system for whole blood: impact on Leishmania donovani infectivity. Transfusion. 2012;52:212A.

10 Fast LD, Nevola M, Tavares J, Reddy HL, Goodrich RP, Marschner S. Treatment of whole blood with riboflavin plus ultraviolet light, an alternative to gamma irradiation in the prevention of transfusion-associated graftversus-host disease? Transfusion. 2013 Feb; 53(2):373-81

11 Allain JP, Owusu-Ofori AK, Assennato SM, Marschner S, Goodrich RP, Owusu-Ofori S. Effect of Plasmodium inactivation in whole blood on the incidence of blood transfusiontransmitted malaria in endemic regions: the African Investigation of the Mirasol System (AIMS) randomised controlled trial. Lancet. 2016 Apr;387(10029):1753-61.

12 FASEB. Evaluation of the health aspects of riboflavin and riboflavin-5 '-phosphate as food ingredients. Prepared for Bureau of Foods, Food and Drug Administration Department of Health, Education, and Welfare. SCOGS114. Washington: FDA; 1979. p. 1-25.
13 Reddy HL, Dayan AD, Cavagnaro J, Gad S, Li J, Goodrich RP. Toxicity testing of a novel riboflavin-based technology for pathogen reduction and white blood cell inactivation. Transfus Med Rev. 2008 Apr;22(2):133-53.

14 Marschner S, Goodrich R. Pathogen Reduction Technology Treatment of Platelets, Plasma and Whole Blood Using Riboflavin and UV Light. Transfus Med Hemother. 2011; 38(1):8-18.

15 Goodrich RP, Murthy KK, Doane SK, Fitzpatrick CN, Morrow LS, Arndt PA, et al. Evaluation of potential immune response and in vivo survival of riboflavin-ultraviolet light-treated red blood cells in baboons. Transfusion. 2009 Jan;49(1):64-74

16 Okoye OT, Reddy H, Wong MD, Doane S, Resnick S, Karamanos E, et al. Large animal evaluation of riboflavin and ultraviolet lighttreated whole blood transfusion in a diffuse, nonsurgical bleeding porcine model. Transfusion. 2015 Mar;55(3):532-43.

17 Lowry OH, Passonneau JV, Hasselberger FX, Schulz DW. Effect of ischemia on known substrates and cofactors of the glycolytic pathway in brain. J Biol Chem. 1964 Jan;239:18-30.

18 Fung MK. AABB Technical Manual. Bethesda (MD): AABB; 2015.

19 Guidance for Industry: Pre-Storage Leukocyte Reduction of Whole Blood and Blood Components Intended for Transfusion, 2012,

20 El Kenz H, Corazza F, Van Der Linden P, Chabab S, Vandenvelde C: Potassium content of irradiated packed red blood cells in different storage media: is there a need for additive solution-dependent recommendations for infant transfusion? Transfus Apher Sci. 2013; 49(2):249-53.

21 Serrano K, Chen D, Hansen AL, Levin E, Turner TR, Kurach JD, et al. The effect of timing of gamma-irradiation on hemolysis and potassium release in leukoreduced red cell concentrates stored in SAGM. Vox Sang. 2014 May;106(4):379-81.

22 Holme S, Elfath MD, Whitley P. Evaluation of in vivo and in vitro quality of apheresis-collected RBC stored for 42 days. Vox Sang. 1998;75(3):212-7.
23 Qu L, Triulzi DJ: Clinical effects of red blood cell storage. Cancer Control. 2015 Jan;22(1): 26-37.

24 Meyer EK, Dumont DF, Baker S, Dumont LJ. Rejuvenation capacity of red blood cells in additive solutions over long-term storage. Transfusion. 2011 Jul;51(7):1574-9.

25 Heaton A, Keegan T, Holme S. In vivo regeneration of red cell 2,3-diphosphoglycerate following transfusion of DPG-depleted AS-1, AS-3 and CPDA-1 red cells. Br J Haematol. 1989 Jan;71(1):131-6.

26 Cancelas JA, Slichter SJ, Rugg N, Pratt PG, Nestheide S, Corson J, et al. Red blood cells derived from whole blood treated with riboflavin and ultraviolet light maintain adequate survival in vivo after 21 days of storage. Transfusion. 2017 May;57(5):1218-25.

27 FDA. Red blood cell workshop: pre-clinical evaluation of red blood cells for transfusion. Bethesda: FDA; 2016.

28 Al-Lawati A, Murch N. Acquired methemoglobinaemia. Sultan Qaboos Univ Med J. 2012 May;12(2):237-41

29 Olson J, Talekar M, Sachdev M, Castellani W, De la Cruz N, Davis J, et al. Potassium changes associated with blood transfusion in pediatric patients. Am J Clin Pathol. 2013 Jun; 139(6):800-5.

30 Brecher ME. Technical Manual. Bethesda (MD): AABB; 2005

31 Sihler KC, Napolitano LM. Complications of massive transfusion. Chest. 2010 Jan;137(1): 209-20.

32 Smith HM, Farrow SJ, Ackerman JD, Stubbs JR, Sprung J. Cardiac arrests associated with hyperkalemia during red blood cell transfusion: a case series [table of contents.]. Anesth Analg. 2008 Apr;106(4):1062-9.

33 Blake JT, Hardy M, Delage G, Myhal G. Déjàvu all over again: using simulation to evaluate the impact of shorter shelf life for red blood cells at Héma-Québec. Transfusion. 2013 Jul; 53(7):1544-58.

34 Grasas A, Pereira A, Bosch MA, Ortiz P, Puig L. Feasibility of reducing the maximum shelf life of red blood cells stored in additive solution: a dynamic simulation study involving a large regional blood system. Vox Sang. 2015 Apr;108(3):233-42. 